IRA-International Journal of Education \& Multidisciplinary Studies

ISSN 2455-2526; Vol.04, Issue 01 (2016)

Institute of Research Advances

http://research-advances.org/index.php/IJEMS

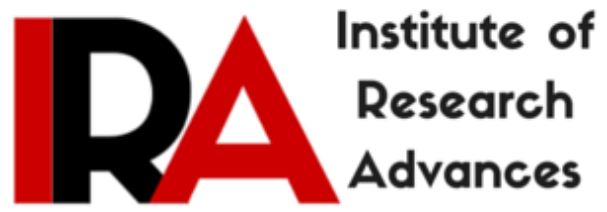

\title{
Vivekananda's View on Uplift of the Subalturn
}

\section{Swapan Kumar Sarkar}

Assistant Professor in History,

Sripat Singh College

Jiaganj, Murshidabad, India.

DOI: http://dx.doi.org/10.21013/jems.v4.n1.p7

\section{How to cite this paper:}

Sarkar, S. (2016). Vivekananda's View on Uplift of the Subalturn. IRA

International Journal of Education and Multidisciplinary Studies (ISSN 2455-

2526), 4(1). doi:http://dx.doi.org/10.21013/jems.v4.n1.p7

(C) Institute of Research Advances

\section{$(\mathrm{cc})$ EY-NC}

This works is licensed under a Creative Commons Attribution-Non Commercial 4.0 International License subject to proper citation to the publication source of the work.

Disclaimer: The scholarly papers as reviewed and published by the Institute of Research Advances (IRA) are the views and opinions of their respective authors and are not the views or opinions of the IRA. The IRA disclaims of any harm or loss caused due to the published content to any party. 


\begin{abstract}
Many great hermits throughout the ages have come of on the holy land of India. Swami Vivekananda is one of those who are especially notable in the field of eco-social, religious and history. He was born in a generous aristocratic "Kayastha" family in North Kolkata. From childhood Vivekananda was very gentle. He easily realizes the circumstances of dependent India. He gets the impression of India and its dignity in the history of mankind; the causes for that position and also whether it is necessary to change - where to start and what is the way. The main streams to culture history in India are - analyzing the relevant objects in traditional way, imperialist attitude, nationalist policy and recently the culture of lower classes history that begins in 1970s. The historians named Ranjit Guha, Partha Chatterjee, Gautam Bhadra, Gayatri Chatterjee, Dipesh Chaterjee et al are notable to initiate this kind of method. It is notable that the method is not very ancient. But Swami Vivekananda was enough to be the greatest in .......lower classes' history in his own time. And it is no doubt that the method is popular and significant. It is my little effort to focus on Vivekananda's thought for the development of backward classes. My effort is based on Vivekananda's "speech", writings, books, and letters and so on.
\end{abstract}

$\underline{\text { Keywords; }}$ uplift, subaltern, brotherhood, socialism, cast system, God and man, shudra, equality.

Swami Vivekananda is an all renouncing hermit. Vivekananda, the extraordinary talented being reaches to the real truth within a lot of interrogation about dissatisfaction comes in touch of Sri Ramakrishna Dev. "Soul is one and unique" - this great speech of Ramkrishna Dev is noticed in the social movement of Vivekananda. Indian society is a classified society. According to Vivekananda Human history means the adventure of human soul's liberation- Swamiji thinks that reconstruction means to culture how human soul gets liberation. Sankari Prasad Bose remarks - Swamiji himself is history. This history is composed in the shortest period of his life. Much of that history is now matter of discussion and much of those are still undiscussed ${ }^{1}$.

Since ancient time Indian society has been regarded as devotional society and still it is. Here religion is greatly respected. Traditional 'Brahmins', 'Kayastha', 'Baishya' and 'Sudra' were the four classes in that social system. Here the conflict is for royalty. The king's demand for monarchy in respect of their caste and common people's distress against the priest's facilities may be softened temporary but the main cause, social division, is not uprooted. In present India, the equality of spiritual thought may be accepted but the divisional social system that had been in ancient time, is still in modern India ${ }^{2}$. Swamiji was very conscious about social exploitation. He finds the exploitation in the Indian society. Vivekananda has focused of the three castes- 'priest, King, and Citizen' ${ }^{3}$ while explaining the social exploitation. Even after being independent we have different in our caste. Religion is mainly accused for that, not only religion but eco-social system and political position are also responsible. The priest- ridden system is naturally cruel and piteous. For that religion is declined where priest-ridden system is established. Priesthood is the sword of exploitation and religion is the weapon for attacking on specified opportunism $^{4}$. The idea is mainly of Hindus. But India is not only for Hindus to live. Many people from various religions have been coming here since ancient times. Throughout that entries India has become a tryst of humanity and museum of anthropology. Muslims and their religion is another main factor amongst nation and religious difference. Difference between Hindus and Muslims; religious envy and mutual fighting are very natural and eternal truth. Can we dissent it? Recent (in 2006 and 2007) both the 'Sachar committee' and 'Ranganath committee' may have some difference in their thought but both of those are same and unique in fundamental principal. In the national ministry now backward Muslims are the matter of discussion and the authority is trying to have a way out in India. The both committees have remarked that Muslims are financially backward like the scheduled castes and scheduled tribes. Even they 
are very badly in their position in some specified field. So the committees are trying to give them special opportunity in the jobs of any government or nongovernment organization.

W. W. Hunter says, "There was no poor Muslim in 1870 but now it is exactly the opposite. Before a hundred and seventy years ago it was impossible for him/her to be rich ${ }^{5}$. Rabindranath Tagore says about this Hindu-Muslim difference in 1904 in his 'Muslim Chhatrer Bangla Sikshak' -"In our country Hindus and Muslims have been exchanging their manners and customs, get up, language and art since ancient time but it is very deadly to be unknown about those close neighbour Bengali Hindus and Muslims have a blood relation" that must not be forgotten ${ }^{6}$. But Vivekananda knew this eternal truth since a long ago. Did we know? If we knew, why didn't we understand? The first vow of Vivekananda's life was to revive the dying Hindus. But he had some respect for Muslims as for the other religions. What is good in Mohammad's religion? Vivekananda says against it that there must be something good in it otherwise it won't stay so long? . What is good must be durable, others may reach to an end, but what is good never be destructed. What is good is simple and durable. So that is ever lasting. There are many good customs in Muslim religion. Mohammed the tutor of communism, the introducer of brotherhood amongst Muslims as well as amongst all human beings, is an eminent personality sent by the God ${ }^{8}$. Vivekananda admires Hazrat for destroying the priest-ridden system. It is only Muslims who were able to dash the priesthood completely ${ }^{9}$.Swamiji realized that "Every religion is only evolving the a God out of the material man and the same God is inspirer of all of them." 10

Swami Vevekananda was an all renouncing permit in spite of being an illusionist in mature religious life he says to dispel individual illusion and to recover whole community from illusion. He says about the Hindus'- loss of power and political decline - that Indian politics is declined because of those community amongst whom the entire knowledge was limited and who were very careless in circulating the knowledge in among the other community. He did not only advice to remove those facts but also tried to revive the Hindus throughout the awareness of 'Sudras'. The polymorphic conscience, who takes responsibility to make Bengal, Bengali, Indian and all mankind conscious, to complete the basic effort of purifying the society and religion leaded by the Bengalis educated in western education, is Swamiji con rejecting. He refused to accept the policy of accepting the western culture indiscriminately for a dependent country and nation. Instead he says exchange won't be one sided. ${ }^{11}$ he will accept the western wealth and science in return of Eastern spiritualism. ${ }^{11}$ Vivekananda was an action personality. So Sri Ramkrishna's thoughts became embodied by the working effort of Vivekananda. ${ }^{12}$ We need not take the headache if there should be any caste distinction in traditional social system or whether the women will get complete independence. ${ }^{13}$ But Vivekananda had the headache how to progress the nation as well as the country? So wanted the circulator of the 'Vedanta' to teach history and geography and thus the will be an unprecedented consciousness through the teaching. ${ }^{14}$ That is why he wanted a complete growth of mankind depending upon religion a media of mass education. ${ }^{15}$ Swamiji did not believe in the difference between man and women as didn't have in caste distinction. Because he believed that our soul is unique/ he realized that the traditional social system and its custom are incurable diseases. He tried his best to make it cured. According to Sunit kumar Chaterjee a great linguist Swami Vivekananda is a lover of mankind, a person sacrificing his life in the service of human being and above all a patriot refined intellectual and an international humanist. ${ }^{16}$ according to him the progress of society, country and nation is impossible by deducting any caste or religion everyone should have an active participation as their ability, in the progress of the country. Basically the old views about the women have turned them a maid to conceive baby and made their lives miserable. Thus accusing the women the men have been turned into beasts, stays and poor. ${ }^{17}$ Vivekanand showed the way to be free from slavery, how to be human from beast. So he advised to make the women able in working out their problems themselves. No one should work instead of them or even should not try to do so. We know that the women in our country have the ability to get the cove as the others. ${ }^{18}$ 
Swami Vivekananda did not believe in European socialism. He believed in Marxist socialism and he was realist in applying Marxism. He said that caste distinction had planted a poison tree in the field of holy India. He believed in caste uniformity he had great trust on it.19 his trust is noticed in explaining intellingentsia in Kolkata where M.R.Akhatar Mukul is found very attacking but swamiji stepped out by circulating his own philosophy there he used the native words like, 'muchi' 'methor' 'chandal' etc. his motive was to avoid peasant revolution and awareness very cleverly. That was why he did not utter a word about the unbridled exploitation of Bengali landlords and peasant revolution in any of his speech, ${ }^{20}$ letters or essays. according to him the cause of declined of our country is selfishness. Vivekananda desires that the selfishness of wealthy people and their effort to keep intact their monocracy must be destroyed. There will be a rule of working people. It will come through revolution. None can't prevent it. According to him, there will be time when 'Shudra' will be rulers. Socialism, anarchism, nihilism will be the progressive flag of this revolution. ${ }^{21}$ Vivekananda praised for liberated mankind. He thinks an ideal society will built up by sincere co-operation of those patriotic to liberated people who are based on scientific thoughts. In this society working and lower classes people will be the protagonist.

Swamiji's new India is practically new India. This India will be found in the thought of 'Bharat Mantra' Vivekananda said- 'Bala Brahmin Bharatbasi, Chandal Bharatbasi amar bhai, Bahu satabdir Jatpat dirna-bidirna Samaje Tini Chandal Bharatbasike bhai bale grahaner ahawan Janiea-with the clarion declaration initiated the growth work of a radical reform of society. So Vivekananda could say "Natun Bharat beruk, beruk langaldhare chashar kutir bhed kare, Jele, Malo, muchi, metharer Jhuprir Madhya hate. Aislamik bhatritwabodhkeo chhapie giechhen Vivekananda. So he has left voices towards advance class of society". Jiban sangrame ryasta thakte nima srenor lokeder jnan unmesh etadin haini..... tora ei mass er bhetar vidyar unmesh jate hoi, tate lageja, Eder bujhye bologe "Tomra amader bhai Shariver Ekanga amra Tomader Valobasi, Ghrina Korina, Era jakhan Jagbe or ekdin jagbe nischay- takhan tarao toder krita upakar bismrita habena. ${ }^{22}$ Vivekananda emphatically believed that this great change would come over India with the uplift and upsurge of the so called "Sudras" that is the down-tradition. Vivekanda comment-"E desher kath ki baliba? Shudrader katha dure thakuk, Bharater brahinnya elehone adhyapak gouranga, kshatritya Bij Chakraborty Engrej, Baishatya o Engrejer Ashti Majjai; Bharatbasi

Kebal Bharabahi Passuta, Kebal Shudratwa. ${ }^{, 23}$ Actually Vivekananda setup human being in the seat of god and this god in satisfied with the progress of this human God.

\section{Conclusion}

From the above discussion it is proved that soul is single and indivisible without any difference. Caste system, untouchability, religion etc do not stand against the formation of a nation. We are the aparks of the very eternal Brahmagni. We being the karmayogi, should plunge into the flow of work. Swamiji shope in regards to the awakening of the shudras has largely been fulfilled. Even today we may hope of being capable to do away with the set backs in the society to rebuild a state and nation with our auspicious wisdom and the blessings of Swami Vivekananda. The social equality may be set up by attaining society without class through the rise of the lower class. Where there will be exploitation deprivation tortures nor caste system there is love and affection ideal learning humanity fraternity, fellowfeeling man in the seat of god and where there be religion, there be the religion of humanity and man will be the member of spiritual imperialism. The conquer of humanity will be sung only for the human beings. And that'll be the greatest conclusion of our tribute to Swami Vivekananda. 


\section{$\underline{\text { Reference }}$}

1. Sankari Prasad Basu, Swami Vivekananda ,Natun Tathya Natun Alo, Ananda Publishers Kolkata, 2011, Preface.(in Bengali)

2. Swami Vivekananda, Bharater Oitihasik Kramabikas Bani O Rachana, Vol.V ,Udbodhan Karyulaya, Kol, 1369, P- 338. (in Bengali)

3. Purba Sengupta, Swami Vivekanander Bhabnay Samaj Bibartan, Paschim Banga, Vivekananda Sankhya, January 2004, P- 127. (in Bengali)

4. Swami Vevekananda, Bharater Oitihasik Kramabikas,Vol III, p- 382. (in Bengali)

5. Mainul Hossain, Hunter Theke Sachar: Bhatater Musalmander Artha Samajik Abastha, 2010, Biswabangiya Prakashan, Kolkata, P- 69. (in Bengali)

6. $\quad$ PrashantaKumar Pal, Rabi Jibani,Vol- IV, Ananda Publishers, $2^{\text {nd }}$ Ed, Kolkata, pp. $302-303$.

7. Swami Vivekananda; Jagater Mahattam Acharya Gan, Mahapurus Prasanga, Udbodhan Karyalaya Kolkata - 1379 B.S, P-29.

8. $\quad$ Ibid, P- 79 .

9. $\quad$ Swami Vevekananda, Bani O Rachana, Vol, III, op, cit., P- 137.

10. The complete works of Swami Vivekananda,Vol- I,Advaitya Ashram, Calcutta, $6^{\text {th }}$ reprint, P- 18. (in Bengali)

11. Subrata Ray O Asoke Kr. Ray( ed) Bahurupe Swamiji, Mitram Prakasani, 2013, Kolkata, preface.

12. Narendranath Bhattachariya, Bharitiya Dharmer Itihas, General printers and publishers, Kolkata-1384 B.S. P- 443 .

13. Swami Vivekananda, Bani O Rachana, Vol-VI, op.cit., P- 391.

14. Sudhindra Nath Bhoumik, Nabyabange Rashtra Chinta Dhara (1815-1905), Paschim Banga Rajya Pustak Parshad, Kolkata - 1981, P- 268.

15. Nihar Majumdar, Swadhinata Andolane Sri Ramkrishna Sangher Bhumika,Vostak, Kolkata, 1993, P- 22.

16. Suniti Kumar Chattopadhyay, Swami Vivekanander Obodan, Paschim banga Vivekananda Sankha, 2004, pp. $37-38$.

17. Swami Vivekanandar Bani O Rachana ,Vol -VI, op.cit., pp - 366-368

18. Ibid. Vol-IX, P-479.

19. Pranabesh Chakraborty, Vivekanander Krishi Chinta, Chintanayak Vivekananda, Kolkata, 1971, Swami Lokeshwaranander Bhumika Angsha, pp- 318-319

20. M.A. Akhter Mukul, Kolkata Kendriya Budhijibi, Sagar Publishers, Dhaka, 1987. P- 152.

21. Tapas Basu (ed), Swami Vivekananda O Marx Badider Drishtite, N.B.A. Kolkata 2012, P- 55.

22. Swami Vivekanander Bani O Rachana, Vol-IX, op.cit. pp- $108-110$.

23. 'Bartaman Bharat', Bani O Rachana (2011) Vol-VI, op.cit. pp- 187. 